\title{
CONDUCTING OTHER PEOPLE'S AFFAIRS WITHOUT A POWER OF ATTORNEY IN A PANDEMIC: POLAND AND UKRAINE
}

CONDUCIR LOS ASUNTOS DE OTRAS PERSONAS SIN UN PODER EN UNA PANDEMIA: POLONIA Y UCRANIA

\author{
Piotr Mysiak ${ }^{*}$ \\ Volodymyr Zubar** \\ Dmytro Pestruiev ${ }^{* * *}$
}

\begin{abstract}
The Covid-19 coronavirus pandemic has caused changes in all areas of human life. The field of law is no exception to this list. In particular, the issues of conducting other people's affairs without a power of attorney have become especially relevant, as social distancing and restrictions on social activity have led to a significant increase in the practical need for the application of this legal institution. The significance of this study is also important in connection with the comparative analysis of the normative aspect and the practical measurement of the application of the institute of conducting other people's affairs without a power of attorney in Ukraine and Poland. These two countries are comparable in territory, number of citizens, legal tradition, but Poland has become member of the European Union, while Ukraine has remained on the sidelines of European civilization. The dialectical method, the method of comparative analysis and system analysis were chosen as the methodological basis of the research. The authors of the
\end{abstract}

\footnotetext{
* Ph.D., Associate Professor of Institute of Legal Studies of University of Zielona Góra (Poland). https://orcid.org/0000-0003-1019-5190. mysiak.piotr@gmail.com

** Ph.D., Associate Professor of Civil Law Department of National University "Odesa Law Academy" (Ukraine). https://orcid.org/0000-0003-4349-068X.v.zubar@gmail.com

*** Ph.D. candidate, Civil Law Department of National University "Odesa Law Academy" (Ukraine). https://orcid.org/0000-0001-6832-3656.d0955555533@gmail.com
} 
article concluded that institute of conducting other people's affairs without a power of attorney is characterized by an increased level of social utility. In such cases, the one who protects the interests of others without a power of attorney, as a rule, acts not only in the interests of the individual but also in the interests of the society. Thus, it helps to protect single people, the elderly ones, disabled individuals and other groups which are socially unprotected and thus prevent the pandemic spread.

Keywords: Negotiorum Gestio, Conducting Other People's Affairs without a Power of Attorney, Legal Altruism, Quarantine, Coronavirus

Resumen: La pandemia del coronavirus Covid-19 ha provocado cambios en todas las áreas de la vida humana. El campo del derecho no es una excepción a esta lista. En particular, la cuestión de la conducción de los asuntos ajenos sin poder notarial ha cobrado especial relevancia, ya que el distanciamiento social y las restricciones a la actividad social han provocado un aumento significativo de la necesidad práctica de la aplicación de esta institución jurídica. La importancia de este estudio también es significativa en relación con el análisis comparativo del aspecto normativo y la medición práctica de la aplicación del instituto de realizar negocios de otras personas sin poder en Ucrania y Polonia. Estos dos países son comparables en territorio, número de ciudadanos, tradición legal, pero Polonia ha llegado a ser miembro de la Unión Europea, mientras Ucrania se ha mantenido al margen de la civilización europea. El método dialéctico, el método de análisis comparativo y el análisis de sistemas fueron elegidos como base metodológica de la investigación. Los autores del artículo concluyeron que el instituto de conducción de los asuntos de otras personas sin poder notarial ofrece mejores niveles de utilidad social. En tales casos, quien protege los intereses de los demás sin un poder, por regla general, actúa no solo en interés del individuo sino también de la sociedad. De esta forma, ayuda a proteger a personas solteras, mayores, gente con discapacidad y a otros grupos que se encuentran desprotegidos socialmente, ayudando a prevenir la propagación de la pandemia.

Palabras clave: Negotiorum Gestio, Dirección de asuntos de terceros sin poder notarial, altruismo legal, cuarentena, Coronavirus

Summary. I. Introduction. II. Methodology. III. Analysis of recent research. IV. Results and discussion. IV.1. Exacerbation of the Problem of Non-Contractual Civil Obligations during the Covid-19 Pandemic. IV.2. Existing Legal Regulation of Non-Contractual Legal Relations and Issues of Altruism in Its Context. IV.3. 
Conducting Other People's Affairs Without a Power of Attorney in a Pandemic...

Justification of Interference and Restriction of Property Rights on the Example of a Lease. VI.4. Minimization of the Harm for Conducting Other People's Affairs Without a Power of Attorney. V. Conclusions. References.

\section{INTRODUCTION}

The emergence and subsequent uncontrolled spread of coronavirus infection (Covid-19) has had some legal consequences, as normal lifestyles have been changed at the state level. On March 1, 2020, the World Health Organization (WHO) declared coronavirus Covid-19 a global pandemic, as the disease, which was unknown to the world health officials three months before that, quickly spread to more than 121,000 people in Asia, Europe, the Middle East, and parts of the United States (Pogorely, 2020). Despite attempts to reduce the harmful effects of quarantine, its debut has made it impossible for a fairly large group of citizens to handle their rights and perform their duties in civil relations, as well as in other, non-contractual relationships. Thus, there is an urgent need to analyze the specifics of such type of relations, as running other people's affairs without a power of attorney in quarantine.

The start of quarantine (and restrictions accompanying this regime) has made it impossible for subjects of civil law to exercise their rights and perform duties in civil law, as well as increased the frequency of cases of conducting other people's affairs without a power of attorney. It is necessary and expedient to carry a comprehensive study of the peculiarities of relations arising from the conduct of other people's affairs without a power of attorney in quarantine. At the same time, given the proximity of the legal systems of Poland and Ukraine, it is of considerable interest to apply the rules of the institute of conducting other people's affairs without a power of attorney in Polish civil law in the conditions of imposing restrictions related to the coronavirus. Therefore, further research of this institute is carried out on the example of the legislation of Ukraine and Poland in the settlement of relevant relations.

The purpose of the article can be formulated as an analysis of the peculiarities of the conditions and consequences of activities in the interests of another person without a power of attorney in quarantine on the materials of Ukraine and Poland. The objectives are to establish the most frequent and typical cases and features of conducting other people's affairs without a power of attorney in the conditions of quarantine as a result of the pandemic. 


\section{Methodology}

To achieve the goals of the article the research was conducted with the help of different scientific methods.

The dialectical method was used in subsections 1 and 3 of section 4 to consider and study the unity of causes and consequences of the increase in the number of non-contractual relationships during the quarantine of the Covid-19 pandemic. The dialectical method, the method of comparative analysis, system analysis were chosen as the methodological basis of the research. They allowed to analyze the institution conducting other people's affairs without a power of attorney, to reveal its legal nature, as well as its specifics in connection with activities for the benefit of another person as a psychological feature of man.

In addition to the above method, in the subsections 2 and 3 of section 4 a system-structural method was used, which allowed to study state policy and legislation in the field of foreign affairs without a power of attorney and helped to review the case-law.

The use of sociological and statistical methods (in subsections 1 and 3 of section 4) contributed to the generalization of legal practice, analysis of empirical information related to the research topic.

In subsections 1 and 3 of section 4, the comparative-legal method helped to research and study the legal literature, legislation in the process of studying the relationship between Ukrainian and Polish legislation and legal doctrine. The method of comparative analysis as a comparison of individual legal phenomena and processes to identify their similarities and differences served to distinguish similar and different manifestations of the institution of conducting other people's affairs without a power of attorney during the Covid-19 pandemic and the introduction of restrictive regimes.

Besides, the methodological specificity of the system approach (which is determined by the focus of the study on the disclosure of the integrity of the object) is to identify various types of connections of a complex object and bring them into a single theoretical picture, manifested in the formulation of the legal nature of the analyzed institution.

The formal-legal method was used in the study of legal sources of scientific work. It made possible to show the specifics of the current legislation of Ukraine, which regulates the activities of entities in the field of foreign affairs without a power of attorney and formulate proposals to improve their activities (in subsections 3 and 4 of section 4). 


\section{ANALYSIS OF RECENT RESEARCH}

The papers on different legal aspects during the Covid-19 pandemic has already appeared. On April 20, 2020, Columbia University published a monograph "Law in the Time of Covid-19", which examines various aspects of lawmaking and its functioning in a pandemic: threats to human rights, public life and social assistance, private life, economic problems. Similar study appeared also in Ukraine (Pistor, 2020).

Regarding the study of the institute of conducting other people's affairs without a power of attorney in Ukrainian law, Kharytonov (1980, 2014), Golubeva (2013), Ignatenko (2010), Kuzmych (2016), Chepys (2016) have referred to this issue (in terms of the characteristics of the respective obligations).

One of the most detailed study of the institute of conducting other people's affairs without a power of attorney emergad in Polish civil law is the work of Drapala (2010) "Conducting another's affairs without a power of attorney. Legal construction." In his thorough work, the scientist study on the development of the institution negotiorum gestio, its understanding as a legal structure, the differences between the concept of conducting other people's affairs without a power of attorney and legal regulation in different legal systems. The attention is paid to the structure and content of legal relations that arise in the conduct of other people's business without a power of attorney, the scope of negotiorum gestio, and other problems that arise in the conduct of relevant activities in the interests of others. The work is currently the most detailed and meaningful study of this institution in Polish civil law.

Various aspects of the problems of legal regulation of relations arising from the conduct of other people's affairs without a power of attorney were also touched upon by Ludwiczak (1960), Kruszynska-Kola (2016), and Blicharz (2010). However, today there are no studies of the institute of conducting other people's affairs without a power of attorney in quarantine, both in Ukrainian and Polish law.

\section{RESULTS AND DISCUSSION}

\section{IV.1. Exacerbation of the Problem of Non-Contractual Civil Obligations during the Covid-19 Pandemic}

Speaking about the change of the usual legal regime to the quarantine regime with the gradual induction of restrictions, it should be noted that Ukraine initially introduced a quarantine regime, which is established and 
abolished by the Cabinet of Ministers of Ukraine under the Law of Ukraine "On Protection of Infectious Diseases". Quarantine was established by the Resolution of the Cabinet of Ministers of Ukraine of March 11, 2020, $\mathrm{n}^{\circ} 211$ "On prevention of the spread of acute respiratory disease Covid-19 caused by coronavirus SARS-CoV-2" for the period from March 12 to April 24, 2020. Within the quarantine:

(i) the work of business entities is prohibited, which provides for the reception of visitors, including catering establishments (restaurants, cafes, etc.), shopping and entertainment centers, other entertainment establishments, fitness centers, cultural institutions, trade, and consumer services; and,

(ii) it is recommended to enterprises, institutions, organizations to ensure the organization of shift work of employees, and if technically possible, also work in real-time via the internet.

In addition, the Resolution of the Cabinet of Ministers of Ukraine of March 25, 2020, $\mathrm{n}^{\circ}$ 388-r established a state of emergency throughout Ukraine until April 24, 2020. The decree indicates the general obligation of enterprises, institutions, and organizations, regardless of the form of ownership, to take measures within the limits and to the extent necessary to eliminate the consequences of the emergency situation, but no restrictions were imposed.

As these regulations had introduced restrictions that could lead to noncompliance with civil law and other agreements, on March 30, 2020, the Verkhovna Rada of Ukraine adopted the Law of Ukraine "On Amendments to Certain Legislative Acts of Ukraine Aimed at Providing Additional Social and Economic Guarantees due to the spread of coronavirus disease (Covid19)". Law $n^{\circ} 540-I X$ introduces a number of measures related to the coronavirus Covid-19 that will have a direct impact on civil law relations:

(i) "freezes" the statute of limitations, i.e. postpones the cut-off period when it is possible to apply to the court in connection with the breach of contractual obligations by another party, for the period of quarantine (until April 24, 2020);

(ii) provides for the possibility of exempting tenants from payment for the use of the property for the period of quarantine established by Resolution $\mathrm{n}^{\circ} 211$ (from March 12, 2020, to April 24, 2020), in case of impossibility to use such property;

(iii) prohibits the increase of the interest rate under credit agreements for the term of quarantine (until April 24, 2020); and,

(iv) make changes to the regime of customs, tax, and labor regulation of enterprises. In case of extension of the quarantine period by amending 
Resolution $\mathrm{n}^{\circ} 211$, the measures listed in Law $\mathrm{n}^{\circ}$ 540-IX will also be extended.

Poland has also introduced measures aimed at reducing the undesirable negative consequences of quarantine, the so-called "Crisis Shield" (Praktyczny przewodnik po instrumentach wsparcia i rozwiązaniach antykryzysowych, 2020). The Law of March 31, 2020 introduced tax benefits for the quarantine period, postponement (suspension) of procedural deadlines, deadlines for tax returns, the extension of loan repayment terms, etc. (O zmianie ustawy o szczególnych rozwiązaniach związanych $\mathrm{z}$ zapobieganiem, przeciwdziałaniem i zwalczaniem Covid-19, innych chorób zakaźnych oraz wywołanych nimi sytuacji kryzysowych oraz niektórych innych ustaw, 2020).

Regarding the problems that affect the normal civil circulation, Polish lawyers say that the coronavirus is the basis for "suspension" of contracts for a period of legal prohibition of trade, in which the owner of the retail space cannot demand payment under the lease agreement (Rudak, 2020), the impossibility of execution of sentences (Krupa, 2020), problems with renewal of terms (Patrycja Rojek-Socha, 2020a), the inability of fulfillment of obligations on payment of alimony (Patrycja Rojek-Socha, 2020b), etc.

Despite attempts to reduce the harmful effects of quarantine, its introduction has made it impossible for a fairly large group of citizens to exercise their rights and fulfill their obligations in civil law, as well as to create other, non-contractual relationships.

In particular, situations have become more frequent when certain circumstances motivate persons who do not have the appropriate authority to voluntarily commit any actions in the property interests of another person. As a rule, the factors of such actions are the sudden emergence of the danger of adverse property consequences for another person, which can be avoided only by taking appropriate measures, the lack of prior consent to perform these actions. In this case, the other person may be in another place, and be in a state where he or she is unable to make any decision on their own.

With the application of quarantine and the introduction of the state of emergency, all long-distance connections were stopped, and, therefore, a person could be in a place other than his or her property, which could be in danger, with the simultaneous inability to get to it. In addition, a person may be in self-isolation when returning from places dangerous for infection, or in treatment when a diagnosis of coronavirus Covid-19 is confirmed, and as a result, be unable to perform their duties under civil law contracts.

There are many examples of conducting other people's affairs without a power of attorney from the person concerned - from paying separate bills for a person temporarily absent from the place of residence (neighbor, friend, 
relative, etc.) or feeding a neighbor's dog or cat (another pet) whose owner suddenly got to the hospital, before the sale by the carrier of the goods entrusted to him by the owner in the event of an unexpected threat of damage to the latter.

The results of the survey conducted by the sociological group "Rating" in cooperation with the National Research Network "Pollaris" conducted at the beginning of the quarantine are obvious. Thus, according to the results of all three waves of surveys conducted from March 27 to April 12, there is a gradual increase in signs of depression, fatigue and sleep disorders and a gradual decline in anxiety and panic.

These phenomena are especially noticeable among the middle age group (30-49 years) and pre-retirement age (50-59 years). That is, the most economically active part of the population, the breadwinners of their families, feel the greatest pressure. The decline in anxiety cannot be assessed separately from other psychological phenomena, as it may indicate both a person's adaptation to new conditions and the transition to depression, as evidenced by the growth of its dynamics, as noted by the Doctor of Psychological Science, Marianna Tkalych (2020).

These circumstances, in our opinion, should also include the negative impact of a crisis situation, which can provoke depression. This can also lead to the risk of temporary non-fulfillment of obligations (for example, a single person is difficult to tolerate quarantine). For example, the results of a survey conducted by the sociological group "Rating" again recorded the presence of respondents with signs of depression, anxiety, panic, fatigue, and sleep disorders," said in a statement.

However, it is noted that if we compare the results of the 3rd wave of surveys (April 10-12) with the results of the 1st (March 27-28) and 2nd (April 3-4) waves, we can see an increase in depression and a decrease in the level of anxiety. The level of panic, fatigue, and sleep disorders remains at the previous level. "In the dynamics, there is a noticeable increase in sleep disorders in the middle age group (30-49 years) and fatigue in respondents of pre-retirement age (50-59 years). Nevertheless, among the latter, there is a decrease in the level of anxiety. The same trend is among the oldest," add sociologists (The number of Ukrainian with depression have increased in mid-April, poll, 2020).

A crisis, in its most general form, is defined as a situation that creates a lack of meaning in later life, as a situation of inability to realize the internal needs of one's life (motives, aspirations, values, etc.). The literature (cfr. Turinina, 2017) identifies the following types of critical situations:

- Stress: the inability to implement here-and-now mental principles. 
- Frustration: insurmountable difficulties in the realization of vital motives.

- Conflict: a subjectively insoluble contradiction of motives and values.

- Crisis: situations that contribute to the impossibility of realization of life plans.

These problems have affected not only Ukrainians but also all other residents of the planet. In Poland, scientists are also concerned about the psychological impact of quarantine and coronavirus on human health and behavior (Kowalska, 2020). A study conducted by scientists led to the conclusion that living in quarantine can have a negative impact on mental health, have both short-term and long-term consequences, delayed in time: depression, alcoholism, etc. (Życie w czasie epidemii. Jak kwarantanna wpływa na psychikę?, 2020).

In this state, a person is also unable to adequately respond to threats that arise and, consequently, increases the possibility of non-contractual relations associated with interference in the property sphere of the dominus of another person who acts in someone else's interest for altruistic reasons, which we are currently seeing during the pandemic and the economic and legal constraints of the state to combat it.

\section{IV.2. Existing Legal Regulation of Non-Contractual Legal Relations and Issues of Altruism in Its Context}

In these and similar cases, in compliance with certain conditions specified in the law, a person who acts in the property interests of another person, there are non-contractual obligations between such persons. These obligations have certain legal consequences, as they result in the person concerned having to reimburse the person who conducted the matter without the power of attorney for the necessary costs incurred as a result of such activities.

It should be emphasized that non-contractual obligations mediate relationships that are not typical of the normal direction of life, i.e. anomalous property relations. A common feature that distinguishes noncontractual obligations into a separate group of civil obligations is the lack of contractual relations between the parties to these obligations. The lack of agreement between the parties to non-contractual obligations gives rise to such a characteristic feature as the lack of coordination of the will of the parties to the obligation. So, in such cases, it is a question of conducting someone else's affairs without a power of attorney (Pestruev, 2018).

Conducting other people's affairs without a power of attorney is regulated by the norms of the Civil Code of Ukraine (2003), namely in Chapter 79 "Acting in the property interests of another person without the 
power of attorney." Article 1158 of the Civil Code states: if the property interests of another person are in danger and the consequences unfavorable to him, the person has the right without a power of attorney to take action to prevent, eliminate or reduce them. In essence, obligations arising out of the performance of actions in the property interests of another person without his or her authority are a type of obligations arising out of the prevention of harm (Kharytonov, 2014).

Actions in the property interests of another person (committed without the power of attorney) create to the obligation to reimburse the costs incurred in this connection, not in any cases, but in the presence of the following conditions (Ignatenko, n.d.):

(i) Actions in the interests of another person are committed without his instructions, which means only the gestor's initiative, i.e. the absence of a contract, instruction or promised consent of the person concerned, as well as the obligation by law to take certain actions in the interests of another person. Such are, for example, the actions of a guardian, trustee in the interests of wards, employees of the social protection service, who assist the elderly and the disabled, etc.

(ii) The presence of the danger of adverse property consequences and the focus of actions to prevent, eliminate, or reduce them. The danger must exist at the time of the action, not be imaginary. The legislator points to the direction of action on the period of neutralization of negative impact on property interests, and depending on the situation, it may be a warningprevention of adverse property consequences, elimination - when negative factors began to affect the property interests of dominus, but gestor eliminated them by his actions; reduction, when the negative consequences could not be averted but reduced.

(iii) Since the legislator speaks about the danger of adverse consequences for the dominus, the actions of the gestor should be aimed at obtaining benefits for the person concerned (preservation of property, the fulfillment of obligations to a third party). By their nature, these can be both actual actions (repair of property, protection of property from illegal actions of others) and legal (conclusion of a transaction, payment of a debt). Also, the actions of the gestor should not be contrary to the interests of the dominus, when the dominus, for example, does not want to take care of their property. The requirements for actions in the interests of others to be taken based on the obvious benefit or benefit and the actual or possible intentions of the person concerned and the due diligence and prudence of the circumstances of the case should be taken into account.

(iv) The gestor does not have the opportunity to obtain the consent of the person to act in his or her interest. This is, for example, the absence of 
such a person in his or her place of permanent residence. At the same time, the circumstances require urgent intervention in the affairs of the dominus. When there is no such urgency, and the gestor had the opportunity to obtain the consent of the dominus, the obligation to conduct other people's affairs without a power of attorney does not arise.

(v) A person who acts in the interests of others is aware of what his or her actions are aimed at and does not intend to have another civil obligation. Thus, if the conduct of a person who releases a debtor from a property obligation to a third party implies that he does so not only free of charge but also on a non-refundable basis, then there is a desire to make a gift.

Besides, there are also other conditions:

(vi) The presence of expenses incurred by a person in connection with the commission of actions in the property interests of another person without his power of attorney is what it means to conduct another's business at someone else's expense.

(vii) A person who has committed acts in the property interests of another person without his / her power of attorney shall, at the first opportunity, notify the latter of his / her actions (Ignatenko, 2010).

Thus, the current legal regulation provides a good basis for addressing issues related to non-contractual civil relations, however, in both doctrine and case-law, many nuances and issues are not fully resolved, which jeopardizes the proper implementation of the rights of all participants in these relationships.

Let us consider the example of Polish legal doctrine of altruism in the context of non-contractual relations. In Polish civil law, the institute negotiorum gestio was introduced in the Code of Obligations of 1933, and only in 1964, it was implemented with minor changes to the Civil Code. According to scholars dealing with this issue, this institution is not very popular in Polish civil law, the doctrine is extremely rarely interested in relevant issues, and recently there has been a debate about whether the socalled legal altruism has a right to exist (Kruszyńska-Kola, 2016).

The point is, first of all, that there are doubts as to whether a person who comes to the aid of another person without the latter's request is at all entitled to reimbursement of expenses and the related question of whether the legislator should take care of the interests of such a person, that is, should he support so-called legal altruism? If so, to what extent? Does the institution of conducting someone else's affairs without a power of attorney entail the protection of the rights of a person who has taken appropriate actions, based on the principles of research in the social sciences and humanities, adopted by the legislator? 
The answers to these questions are impossible without studying the problems of altruism and selfishness, which were raised in ancient times by philosophers. It is also interesting to understand the word "altruism" in Polish.

Answering the first question, many philosophers argue that human nature is more suited to selfish behavior, that is, one that inclines man to protect, above all, their own interests. However, there is another group of philosophers, according to whom selfishness coexists with inclinations to charity. It has to do with social life, part of which is altruistic behavior towards other members of society.

Regarding the philological interpretation of the word "altruism", most dictionaries define it as a "long norm of behavior". That is, isolated cases of a charitable nature cannot be attributed to altruism, as it must become, due to long-term recurrence, a certain "philosophy of life." Secondly, the issue that is very important in the definition of altruism, it should apply not only to certain individuals but should reflect the general feature of human behavior - the universal ability to do good deeds (inherent in human nature in general).

And although a single concept of altruism has not yet been formulated, despite all the differences in its understanding, altruism from a psychological point of view can be defined as an activity for the benefit of another person unmotivated by external reward (Rutkowskiej, 2008).

Defining the meaning of psychological altruism, in this case, has a certain meaning, because there is also behavioral altruism as helpful behavior, which can be useful to the person helping and indifferent to it. Psychological altruism, on the other hand, is a motivation to do good to another person as an inner goal that is meaningful to the person.

The very understanding of psychology is taken as a basis by the legislator to formulate the category of conducting other people's affairs without a power of attorney because it is useful both for the individual and for society as a whole. Thus, we can conclude that the basis of legal understanding of the essence of other people's affairs without a power of attorney in Polish civil law is its psychological understanding as inherent in human nature, one that acts for the benefit of both the individual and society as a whole.

\section{IV.3. Justification of Interference and Restriction of Property Rights on the Example of a Lease}

In addition to the issue of legal altruism, which is an integral part of the characterization of someone else's business without a power of attorney, 
there may also be the question of the justification of interfering in someone else's property.

According to Article 41 of the Constitution of Ukraine (1996), no one may be unlawfully deprived of property rights. The right of private property is inviolable. Compulsory expropriation of objects of private property may be used only as an exception for reasons of public necessity, on the basis and in the manner prescribed by law, and subject to prior and full reimbursement of their value. Compulsory alienation of such objects with the subsequent full reimbursement of their value is allowed only in conditions of martial law or state of emergency.

Convention for the Protection of Human Rights and Fundamental Freedoms, ratified by the Law of Ukraine "On Ratification of the Convention for the Protection of Human Rights and Fundamental Freedoms of 1950, First Protocol and Protocols n ${ }^{\circ}$ 2, 4, 7 and 11 to the Convention" of July 17, 1997, $n^{\circ} 475 / 97-B R$, in particular, Article 1 of the First Protocol to it, states: "Every natural or legal person is entitled to the peaceful enjoyment of his possessions. No one shall be deprived of his possessions except in the public interest and subject to the conditions provided for by law and by the general principles of international law. However, the preceding provisions do not in any way restrict the right of a State to enact such laws as it deems necessary to control the use of property in the general interest or to ensure the payment of taxes or other charges or fines".

In the practice of the European Court of Human Rights (hereinafter the "ECtHR"), three main criteria have been developed, which should be assessed for compliance with the interference with the right of a person to peaceful possession of his property to the principle of lawful interference, compatible with the guarantees of Art. 1 of the First Protocol, namely:

(i) whether the interference was lawful;

(ii) whether it pursues a "public interest" (public interest, general interest, the general interest of the community); and,

(iii) whether such a measure (interference with the right to peaceful possession of property) is proportionate to the objectives pursued (must be a reasonable relationship of proportionality between the means employed and the aims pursued). The ECtHR states that the state violated Art. 1 of the First Protocol if at least one criterion is not met (The Supreme Court summarized recommendations on the protection of property rights, 2015).

An analysis of the existing documents suggests that in any case it is a question of interference by public authorities in the peaceful possession of the property, so these rules can in no way be applied to relations arising from the conduct of another's affairs without a power of attorney. 
In the context of the Covid-19 coronavirus pandemic, the most common situation is that most commercial real estate tenants, whose activities are prohibited during the quarantine period, may use the leased premises to a limited or no use at all.

To reduce the burden of negative consequences, the legislation in these conditions gives tenants the right to demand a reduction in rent or exempt them from rent in general, as well as provides an opportunity to initiate the termination of the contract.

The tenant's right to demand a reduction or exemption from rent may arise on the following grounds:

- The possibility of using the premises has significantly decreased - if due to circumstances for which the tenant is not responsible, the possibility of using the leased premises has significantly decreased, he has the right to demand a reduction of rent (Article 762 (4) of the Civil Code);

- Changed the terms of the contract - if due to circumstances for which the tenant is not responsible, the terms of the contract have changed, the tenant has the right to demand a reduction in rent (Article 286 (2) of the Commercial Code of Ukraine); and,

- During the quarantine period, the leased premises could not be used-if due to circumstances for which the lessee is not responsible, the premises could not be used at all, the lessee is exempt from rent for the entire period of such downtime (Article 762 (6) of the Civil Code).

Attention should also be paid to the provisions of Law n ${ }^{\circ}$ 540-IX "On Amendments to Certain Legislative Acts of Ukraine Aimed at Providing Additional Social and Economic Guarantees due to the Spread of Coronavirus Disease (Covid-19)", which to the Final Provisions of the Civil Code Ukraine (2003) added a provision according to which from March 11, 2020, until the end of the quarantine the tenant may be exempt from payment for the use of property under Article 762 (6) of the Civil Code of Ukraine. In connection with this innovation, we pay attention to two key aspects:

- The lessee is not released from the obligation to pay utility bills or marketing fees if these costs are not included in the rent under the lease agreement.

- Law n ${ }^{\circ}$ 540-IX and Article 762 (6) of the Civil Code of Ukraine (2003) are more general in nature and provide for the possibility of exemption from the obligation to pay rent in full, while force majeure only exempts from liability for breach of obligation (Legal consequences of the spread of coronavirus Covid-19 to perform the contract, 2020). 
Thus, conducting other people's affairs without a power of attorney is possible in situations where a person (exempt from payment for the use of property) is obliged to pay utility bills or marketing fees (if these costs are not included in the rent under the lease), but cannot do it himself or herself.

In such cases, the person (gestor) who has paid for another person (dominus) utility bills or marketing fees, must notify the dominus following Part 2 of Art. 1158 of the Civil Code of Ukraine, at the first opportunity. The first opportunity in this case will be the opportunity to contact the person concerned (who may be in the intensive care unit of the hospital, in an area with improper communication, etc.). The gestor has this responsibility, regardless of whether the person concerned could have learned about the actions taken in his favor from other sources. The literature states that (although there is no direct indication of the law) that the gestor, having taken the minimum necessary action, must temporarily cease its activities in the interests of another person (only if it is possible to do so without the significant property damage) to enable the person concerned to notify of his approval of the acts committed for him/her, or conversely, of the refusal of another person to conduct his/her affairs (Dombrugova, n.d.).

If the gestor has not fulfilled his duty to notify the dominus about the actions taken, he loses the right to demand reimbursement of expenses (Part 2 of Article 1160 of the Civil Code of Ukraine). Gestor is aware of the direction of his actions to prevent, eliminate, or reduce adverse effects on the property interests of the dominus.

This is the legal position also held by the Supreme Commercial Court of Ukraine in the decision of June 3, 2013, in the case $n^{\circ}$ 5002-6/2091-2012. The Crimean Republican Enterprise "Production Enterprise of Water Supply and Sewerage of the City of Simferopol" appealed to the Commercial Court of the Autonomous Republic of Crimea with a claim to the Saki Interdistrict Department of Water Management to recover of the costs incurred by the plaintiff for the implementation of measures to protect the reservoir from pollution, clogging and depletion, as well as ensuring the safety of production and supply of drinking water. Thus, in the course of the trial, the court concluded that the plaintiff's letters did not mention actions in the property interests of the defendant, but only the need to take into operation the Intermountain Reservoir. Improper information has led to a refusal to reimburse gestor in this situation.

This restriction is related to the specifics of conducting the affairs of another person without his / her instructions, which is based on the principles of solidarity, taking into account the interests of the subjects of these relations. The need to conduct another's affairs arises when the civil rights and interests of another person are in danger (there is a need to protect the 
property interests of another person). At the same time, the need for arbitrary interference in other people's affairs is conditioned not only by the existence of danger to other people's property interests but also by the fact that the gestor cannot notify the owner and obtain consent from the latter for these actions. Therefore, if it is possible to inform the owner about the actions in his interest, the gestor should do so at the first opportunity, and the one who did not fulfill this obligation loses the right to reimbursement because he did not take into account the interests of the owner. Thus, in the case of the Rivne Court of Appeal (2013) in a situation when the private enterprise "Tymag" without reaching an agreement with the Starovyzhivsky district consumer society performed in his favor repair of the roof, the court concluded that the defendant was clearly against repair work, and therefore is not obliged to reimburse the costs of the plaintiff, even if his actions have preserved the property and improved his property status.

The person in whose interests the action was taken shall be notified to obtain the approval of the gestor's actions and to obtain consent to reimburse the costs incurred in connection with the gestor's actions in the interests of others. Dominus, considering the actions committed in his interests (in these circumstances, appropriate and useful), approves them, thereby agreeing to assume all the consequences of such actions. This rule means that the very fact of approval of non-contractual relations arising from unilateral actions transforms them into contractual obligations of the appropriate type. All costs and other losses of a person who acted in the interest of another, incurred by him in connection with the actions taken after their approval by the person concerned, are reimbursed under the rules of the contract of the relevant type. After that, from the moment of approval and in the further relations between the gestor and the dominus, the provisions of the contract will apply, which will correspond to the nature of the actions taken. In particular, when the gestor provides legal services (for example, concluding agreements or fulfilling any obligations for the person concerned), it will be considered that the parties are in a relationship arising from the power of attorney. If the actions committed in favor of another person consisted of the performance of certain work (caring for an animal), then their approval by the person concerned is compared to the conclusion of a contract, etc.

There are different forms of approval of the actions of a person who acted in the interests of another person, without a power of attorney. In particular, the implicit actions, such as the acceptance of services provided by the gestor or goods purchased by the gestor for the person concerned (Pestruev, 2018). 
A person who has acted in someone else's interest must wait for the decision of the person concerned to approve or disapprove of his actions. Thus disapproval should be expressed in the active form.

Besides, the landlord's actions to protect the tenant's property, preserve it at his own expense, as well as take measures to preserve it and preserve its properties and qualities under various negative conditions are also signs of actions to conduct someone else's affairs without a power of attorney.

As for the non-contractual relations that arise in Poland as a result of the introduction of quarantine and the Covid-19 pandemic, they are also most often related to leases. In particular, since a special law in force in Poland from April 1 temporarily suspends the obligation to pay rent, it also suspends bilateral obligations, and the owner may require the tenant to vacate the apartment. But it is difficult to imagine a situation in which a tenant of retail space could temporarily vacate these areas from the store. In this case, the owner could rather claim compensation for non-payment of rent. The special law contains several gaps, including the lack, in particular, of regulating the regime of goods remaining in retail space during the ban on trade caused by the coronavirus. Using these gaps, the owner could demand from the tenant a fee for storage of the abandoned goods following the provisions of Art. 835-845 of the Civil Code of Poland (1964) (Załucki, 2019).

Besides, scholars pay attention to some other aspects of the suspension of contracts by special law, such as the termination of contracts for the protection of retail space, and here it may be just that the further provision of security services can be qualified as conducting someone else's business without a power of attorney. On this legal basis, the lessee could demand reimbursement of all expenses, together with legal interest, as well as exemption from obligations arising in the conduct of business (Article 753 of the Civil Code of Poland). This could be the basis for commercial facilities to claim at least part of the operating costs incurred in connection with the provision of this type of service (Kozyra, 2020).

In general, this situation has shown that the existing mechanisms for reducing rents were based on other conditions and we currently have many cases in court, both on improper payment of rent and early termination of contracts and issues of non-contractual relations with former partners. In the public interest, the legislature could go from a temporary $50 \%$ rental rate to interest-free loans and tax breaks for businesses, which in turn would reduce the number of non-contractual cases. 


\section{VI.4. Minimization of the Harm for Conducting Other People's Affairs Without a Power of Attorney}

Considering the whole array of data on the features and issues of regulation of non-contractual relations, the logical question is how to minimize the risks. The main recipe, of course, will be the use of classic contractual relations, but in a pandemic, there are some difficulties due to the need for personal meetings or at least the exchange of paper media with all the necessary details. But is it possible to enter into contracts orally or at least through the internet?

As for the moment, the official explanation regarding the choice of the written or oral form of the contract is the Clarification of the Ministry of Justice of Ukraine dated April 19, 2011 "On the form of transactions". Thus, the Ministry of Justice of Ukraine in this matter, first of all, proposes to mention the requirement of Part 4 of Article 203 of the Civil Code: "transactions must be made in the form prescribed by law."

The transaction must be performed in the form prescribed by law - this is one of the main requirements of its validity. If the law defines a specific form in which transactions must be made, it must be followed. In case of non-compliance with this requirement, there are negative consequences (recognition of the transaction as null and void).

According to Article 205 of the Civil Code of Ukraine, transactions may be made orally or in writing. The parties have the right to choose the form of the transaction unless otherwise provided by law.

The law may provide for specific cases of mandatory written form of certain transactions (in certain articles of the Civil or Commercial Codes), but there are also general rules that define the general features under which transactions must be concluded exclusively in writing.

Thus, Article 208 of the Civil Code provides a list of transactions that must be made in writing:

(i) transactions between legal entities;

(ii) transactions between individuals and legal entities, except for transactions provided for in part one of Article 206 (Part 1 of Article 206 of the Civil Code: Orally may be transactions that are fully performed by the parties at the time of their commission, except for transactions subject to notarization and (or) state registration, as well as transactions for which noncompliance with the written form results in their invalidity);

(iii) transactions between individuals in the amount exceeding twenty times or more the amount of the non-taxable minimum income of citizens, 
except for transactions provided for in part one of Article 206 of the Civil Code; and,

(iv) other transactions for which the law establishes a written form.

In all other cases, business entities must be guided by Article 208 of the Civil Code of Ukraine and enter into a contract in writing.

However, it is necessary to pay attention to Part 1 of Art. 181 of the Commercial Code of Ukraine, which states that

"a commercial contract as a general rule is set out in the form of a single document signed by the parties. Business contracts may be concluded in a simplified manner, i.e. by exchanging letters, faxes, telegrams, telephone messages, etc., as well as by confirming acceptance of orders, unless the law establishes special requirements for the form and procedure for concluding this type of contract."

Even though the Code does not explicitly specify the internet, there is a special law "On e-commerce" (2015) which also regulates the conclusion and validity of contracts via the internet. But the use of such a method for concluding a contract carries several new risks and problems: the identification of the parties and the reality of their intention to enter into an agreement, the security of electronic keys, and the danger of confidential and private information. It will also be difficult for legal entities that have previously had limited use of such a means of communication to adapt quickly.

Special attention should be paid to the tax risks for the business entity in case of non-compliance with the written form of the transaction. This is a situation where the transaction due to non-compliance by the parties with the requirements of Art. 208 of the Civil Code (regarding the written form of the transaction) may be declared invalid (null and void) in court. After the entry into force of such a court decision, the buyer must reduce the amount of the previously declared tax credit, as no documents are certifying the right to form such tax credit.

Summarizing all the above, it should be noted that for a legal entity (or individual entrepreneur) under the law, any transaction must be concluded in writing, choosing between a simplified form (Article 181 of the Commercial Code) or a full contract.

Therefore, in today's situation, businesses can be advised to use the traditional paper method of concluding contracts and conducting business activities. As a less secure but still legal measure to use modern communications with the possibility of restoring the full picture of negotiations between the parties. And only in case of impossibility of operative communication to use the theory and practice of non-contractual legal relations which we have considered in this article. 


\section{CONCLUSIONS}

1. The Covid-19 pandemic has led to some negative consequences in civil law relations related to the inability of entities to fulfill their obligations under contracts, the difficulty of concluding new ones, violations of the normal economic life of enterprises and people in connection with quarantine restrictions. All this has affected the growth of non-contractual relations and the problems associated with them.

2. The existing legal framework provides a good basis for addressing issues related to non-contractual civil relations. Based on a psychological understanding of such a concept as altruism, the legislator formulates the category of conducting other people's affairs without a power of attorney, both useful for the individual and society as a whole.

3. The practice of government intervention and restrictions on the activities of economic entities in a pandemic and at the same time the lack of proper legal regulation of the issue of losses, which we considered in the example of commercial leases, is becoming problematic. Existing rent reduction mechanisms have relied on other conditions, and we now have several lawsuits, both for improper rent payments and early termination of contracts and for non-contractual relationships with former partners. In the public interest, the legislature could go from a temporary $50 \%$ rental rate to interest-free loans and tax breaks for businesses, which in turn would reduce the number of non-contractual cases.

4. Another issue is the rather tough stance of the courts on the refusal to reimburse the gestor. But our review of possible situations related to quarantine, when it is justified to interfere in the sphere of property interests of another person, gives grounds to conclude that they are generally characterized by an increased level of social utility.

After all, in such cases, the one who protects the interests of others without a power of attorney, as a rule, acts not only in the interests of the individual but also society. In this way, it helps to protect people from "atrisk" (single elderly, infirm, etc.) from the disease, and thus prevents the spread of Covid-19. Its activities are aimed at promoting the goal of quarantine, which should be taken into account in resolving disputes that may arise in its implementation. We believe that, in such cases, the courts should take into account the public utility of the gestor's actions, involving in necessary cases to reimburse the costs incurred by third parties, due to inaction or improper activity which necessitated actions in the interests of another person without his instructions. 
5. Today, businesses can be encouraged to use the traditional paper method of concluding contracts and conducting business activities, as a less secure but still legal measure to use modern communications: and, only in case of impossibility of operative communication, to use the theory and practice of non-contractual legal relations which we have considered in this article.

\section{REFERENCES}

112 Ukraine. (2020). The number of Ukrainian with depression have increased in midApril, poll. In https://ua.112.ua/suspilstvo/v-seredyni-kvitnia-u-ukraintsivzbilshylas-kilkist-depresii-opytuvannia-533743.html.

Blicharz, G. (2010). Przemysław drapała, prowadzenie cudzych spraw bez zlecenia. Konstrukcja prawna. Warszawa: C.H. Beck. In https://palestra.pl/pl/czasopismo/wydanie/1-2-2012/artykul/przemyslawdrapala-prowadzenie-cudzych-spraw-bez-zlecenia.-konstrukcja-prawna.

Chepys, O. (2016). Institute of negotiorum gestio in modern civil law of Ukraine.

Comparative and analytical law, 1, 119-122. In https://dspace.uzhnu.edu.ua/jspui/handle/lib/16516.

Convention for the Protection of Human Rights and Fundamental Freedoms as amended by Protocols $n^{\circ} 11$ and 14 (1950).

Dombrugova, A. (n.d.). Actions in the property interests of another person without her power of attorney. Law and Normative. In https://www.zakon-inormativ.info/index.php/component/lica/?href=0\&view=text \&base=1\&id=2145 $63 \&$ menu $=323817$.

Drapala, P. (2010). Prowadzenie cudzych spraw bez zlecenia. Konstrukcja prawna. Warszawa: Wydawnictwo C.N.Beck.

Golubeva N. (2013). Obligations in the civil law of Ukraine: methodological principles of legal regulation. Odesa: Phoenix.

Ignatenko V. (2010). Determining the conditions for the occurrence of obligations to act in the property interests of another person without his instructions. Law of Ukraine, 12, 68-73.

Ignatenko, V. (n.d.) Determining the conditions for the occurrence of obligations to act in the property interests of another person without his instructions. Pravoznavets. In http://pravoznavec.com.ua/period/article/6185/\%C2.

Kharytonov E. (2014). The system of obligations arising from the prevention of damage, according to the Civil Code of Ukraine. Kyiv: PJSC "Legal Practice".

Kharytonov, E. (1980). Obligations Arising from Unauthorized Business in Soviet Civil Law. Kharkiv: Odessey.

Kowalska, J.D. (2020). Psychologiczne następstwa kwarantanny i jak im zapobiegać. Medycyna Praktyczna Dla Lekarzy. In 
https://www.mp.pl/poz/psychiatria/depresja/232245,psychologicznenastepstwa-kwarantanny-ijak-im-zapobiegac.

Kozyra, B. (2020). Trzeba szukać rozwiązań poza specustawą. SCF News: Retailnet.pl. In https://retailnet.pl/2020/04/01/27187-trzeba-szukac-rozwiazan-pozaspecustawa/

Krupa, A. (2020). Sędzia Krupa: Czas epidemii - czasem... bezkarności. Prawo.pl. In https://www.prawo.pl/prawnicy-sady/jak-wyglada-wykonywanie-karograniczenia-wolnosci-w-czasie,500284.html.

Kruszynska-Kola, J. (2016). Prowadzenie cudzych spraw bez zlecenia jako wyraz zachowań altruistycznych. Ruch prawnyczy, ekonomiczny i socjologiczny, 1, 127-140. https://pressto.amu.edu.pl/index.php/rpeis/article/view/5293.

Kuzmych O. (2016). Obligations in connection with the commission of actions in the property interests of another person without his power of attorney: problems of qualification in judicial practice. Law and Society, 3, 58-64. In http://www.irbis-nbuv.gov.ua/cgibin/irbis_nbuv/cgiirbis_64.exe?I21DBN=LINK\&P21DBN=UJRN\&Z21ID=\&S $21 \mathrm{REF}=10 \& \mathrm{~S} 21 \mathrm{CNR}=20 \& \mathrm{~S} 21 \mathrm{STN}=1 \& \mathrm{~S} 21 \mathrm{FMT}=\mathrm{ASP} \_$meta $\& \mathrm{C} 21 \mathrm{COM}=\mathrm{S} \& 2$ _S21P03=FILA=\&2_S21STR=Pis_2016_3(1)_13.

Law and Business. (2015). The Supreme Court summarized recommendations on the protection of property rights. In https://zib.com.ua/ua/print/120218u_verhovnomu_sudi_pidsumuvali_rekomendacii_schodo_zahistu_pr.html.

Law firm "Sayenko \& Kharenko". (2020). Legal consequences of the spread of coronavirus Covid-19 to perform the contract. In https://sk.ua/uk/newsuk/pravovi-naslidki-poshirennya-koronavi/.

Ludwiczak, W. (1960). Prowadzenie cudzych spraw bez zlecenia. Warszawa: Wydawnictwo C.N.Beck.

Patrycja Rojek-Socha, P. (2020a). Tarcze mieszają w terminach - nie ma pewności, czy są "zawieszone". Prawo.pl. In https://www.prawo.pl/prawnicy-sady/terminyprocesowe-i-sadowe-zawieszone-czy-nie-watpliwosci,500342.html.

Patrycja Rojek-Socha, P. (2020b). W czasach koronawirusa zaczyna się wojna o alimenty. Prawo.pl. In https://www.prawo.pl/prawnicy-sady/jak-obnizyc-podwyzszycalimenty-w-czasie-koronawirusa,499673.html.

Pestruev, D. (2018). Conducting cases without a power of attorney as a basis for civil rights and obligations. Legal Life of Modern Ukraine, 457-459.

Pestruev, D. (2018). Formation of the concept of legal regulation of another person's affairs without his / her instructions in Ukraine and Poland. Scientific and practical journal "Journal of Civil law", 35, 41-47.

Pistor, K. (2020). Law in the Time of Covid-19. New York: Columbia Law School. In https://scholarship.law.columbia.edu/books/240

Pogorely, V. (2020). The Covid-19 pandemic in the world as a circumstance for nonfulfillment of contract obligations. In https://tk.media/blogs/vladislav- 
Conducting Other People's Affairs Without a Power of Attorney in a Pandemic...

pogorelyy/pandemiya-covid-19-v-sviti-yak-obstavina-dlya-nevikonannyazobovyazan-dogovoru.

Poland. (1964). Civil Code. In https://www.ebrd.com/downloads/legal/core/poland.pdf.

Poland. (2020). O zmianie ustawy o szczególnych rozwiązaniach związanych z zapobieganiem, przeciwdziałaniem i zwalczaniem Covid-19, innych chorób zakaźnych oraz wywołanych nimi sytuacji kryzysowych oraz niektórych innych ustaw. In http://dziennikustaw.gov.pl/DU/2020/568.

Praktyczny przewodnik po instrumentach wsparcia i rozwiązaniach antykryzysowych. (2020). In http://konfederacjalewiatan.pl/aktualnosci/2020/1/_files/2020_04/Praktyczny_p rzewodnik_po_instrumentach_wsparcia_i_rozwiazaniach_antykryzysowych_fi nal_v2.pdf?fbclid=IwAR1IRWLY236jdHW6isphWcVqb4YtDwSJ5OSjFiOT2 8cXOayZz7xv7-B7IEg.

Rating. (2020). Psycho-emotional state of Ukrainians in quarantine: general assessments and dynamics. In http://ratinggroup.ua/research/ukraine/psihoemocionalnoe_sostoyanie_ukraince v_na_karantine_obschie_ocenki_i_dinamika.html.

Rudak, O. (2020). Koronawirusowe „wygaśnięcie zobowiązań” to nie „wygaśnięcie umów”. Czasopismo Lege Artis. In https://czasopismo.legeartis.org/2020/04/koronawirus-wygasnieciezobowiazan.html.

Rutkowskiej, D. (2008). (Ed.). O różnych obliczach altruizmu. Warszawa: Wydawnictwo C.N.Beck.

Tkalych, M. (2020). Psycho-emotional state of Ukrainians in quarantine: general assessments and dynamics. Rating. In.

http://sau.in.ua/research/psyhoemoczijnyj-stan-ukrayincziv-na-karantynizagalni-oczinky-ta-dynamika/

Turinina, O. (2017). Psychology of traumatic situations. Kyiv: "Personal" Publishing House.

Ukraine. (1996). Constitution of Ukraine. In https://zakon.rada.gov.ua/laws/show/254\%D0\%BA/96-\%D0\%B2\%D1\%80.

Ukraine. (1997). On Ratification of the Convention for the Protection of Human Rights and Fundamental Freedoms of 1950, First Protocol and Protocols $n^{\circ} 2,4,7$ and 11 to the Convention: Law 475/97. In https://zakon.rada.gov.ua/laws/show/475/97-\%D0\%B2\%D1\%80\#Text.

Ukraine. (2003). Civil Code. In https://zakon.rada.gov.ua/laws/show/435-15.

Ukraine. (2003). Commercial Code. In https://zakon.rada.gov.ua/laws/show/436-15.

Ukraine. (2015). On e-commerce. In https://zakon.rada.gov.ua/laws/show/675-19.

Ukraine. (2020). On Amendments to Certain Legislative Acts of Ukraine Aimed at Providing Additional Social and Economic Guarantees in Connection with the Spread of Coronavirus Disease (Covid-19): Law 540-IX. In https://zakon.rada.gov.ua/laws/show/540-20. 
wGospodarce.pl. (2020). Stres, depresja-psychiczne skutki izolacji. In https://wgospodarce.pl/informacje/78211-stres-depresja-psychiczne-skutkiizolacji.

Ukraine. Cabinet of Ministers of Ukraine. (2020). On Amendments to Certain Acts of the Cabinet of Ministers of Ukraine: Resolution 239. In https://zakon.rada.gov.ua/laws/show/239-2020-\%D0\%BF.

Ukraine. Cabinet of Ministers of Ukraine. (2020). On prevention of the spread of acute respiratory disease Covid-19 caused by coronavirus SARS-CoV-2 on the territory of Ukraine: Resolution 211. In https://zakon.rada.gov.ua/laws/show/211-2020-\%D0\%BF.

Ukraine. Ministry of Justice. (2011). On the form of transactions: Clarification. In https://zakon.rada.gov.ua/laws/show/n0028323-11.

Ukraine. Rivne Commercial Court of Appeal. (2013). Resolution 35437100. In https://youcontrol.com.ua/ru/catalog/court-document/35437100/.

Ukraine. Supreme Commercial Court of Ukraine. (2013). Decision n 5002-6/2091-2012. In

https://protocol.ua/ru/postanova_vgsu_vid_11_03_2014_roku_u_spravi_5002_ 6_2091_2012/.

Załucki, M. (2019). (Ed.). Kodekscywilny. Komentarz. Warszawa: Wydawnictwo C.N.Beck.

Życie w czasie epidemii. Jak kwarantanna wpływa na psychikę? (2020). In https://www.rp.pl/Koronawirus-SARS-CoV-2/200329713-Zycie-w-czasieepidemii-Jak-kwarantanna-wplywa-na-psychike.html. 